\title{
Al-Qaeda Understandings from Seyed Qutb's Jihadi Thoughts
}

\author{
Hassan Hajizadeh Anari ${ }^{1}$, Reza Jalali ${ }^{2}$, Akbar Ashrafi ${ }^{2}$, Ahmad Bakhshayesh Ardestani ${ }^{3}$, Seyed Mohammad Mehdi \\ Ghasemtabar $^{4}$ \\ ${ }^{1}$ Assistant Professor, Department of Educational Science, Farhangian University \& Department of Political Science, \\ Islamic Azad Central University, Tehran, Iran \\ ${ }^{2}$ Assistant Professor, Department of Political Science, Islamic Azad University Central Tehran Branch, Iran \\ ${ }^{3}$ Professor, Department of Political Science, Islamic Azad University Central Tehran Branch, Iran \\ ${ }^{4}$ Assistant Professor, Department of Educational Science, Farhangian University, Tehran, Iran \\ Correspondence: Hassan Hajizadehanari, Assistant Professor, Department of Educational Science, Farhangian \\ University \& Department of Political Science, Islamic Azad Central University, Tehran, Iran.
}

Received: March 13, 2017

doi:10.11114/ijsss.v5i7.2269
Accepted: June 9, $2017 \quad$ Available online: June 19, 2017

URL: https://doi.org/10.11114/ijsss.v5i7.2269

\begin{abstract}
Seyed Qutb is one of the great theorists of Egypt Muslim population who could propagate his thoughts among Egyptian youths and adolescents through writing the books such as "fi zelal al Quran "and "Maalem fe al tarigh". Presenting some problems such as like social justice in Islam, people's Ignorance in present age and world division into Islam and Atheism, He eloquently announced idolatry of all governments and its solution as being Jihad or emigration.

Stating such thoughts influenced Arab youths greatly as after executing him, jihadi groups including Al-Qaeda were created influenced by his thoughts. In their method and thought they followed Seyed Qutb but in jurisprudence and beliefs they imitated salafists like Ibn Tamie; as Abdullah Azam says: I had been the pupil of four persons: In thought the pupil of Seyed Qutb, in jurisprudence pupile of Now; in beliefs the pupil of Ibn Tamie and in mental issues pupil of Ibn Qayem. So Al-Qaeda is a combined group that has adopted his strategic way from Seyed Qutb's thoughts and his beliefs from Ibn Tamie and now we observe that abusing Qutbi's ideas Wahhabism invites Arab youths to war and jihad, but with special goals from which none are accordance with Seyed Qutb's goals.
\end{abstract}

Keywords: Al-Qaeda, SeyedQutb, Vahhabism, ignorance, excommunication, Islam, Atheism

\section{Introduction}

After the event of September $11^{\text {th }}, 2001$ in America 2001, terrorist attack of extreme Islamist group got known by the name of Al-Qaeda in all world media that then became an excuse for America attack to Afghanistan, Iraq and some other countries continuing against this through the world followed by murdering many innocent people until now. It is strictly asked what intellectual and belief base of this group is and where it is originated from? Studying method of creating Al-Qaeda and its leaders' faith thoughts and rules summarily, we will prove that origin of the group's beliefs and thoughts is Seyed Qutb who could incite some Arab youths against west specially America. Of course, Seyed Qutb's thoughts is not total cause and excommunicative Salafism thoughts have played important role on forming Al-Qaeda's thoughts in this time area; as today suicide attacks and war against Muslims especially Sufis and Shias are observed through the world.

Al-Qaeda could improve excommunicative thoughts by combining Seyed Qutb and Wahhabism's and many advocates of Seyed Qutb oppose it nowadays. Al-Qaeda group could follow up its goals by abusing Seyed Qutb's thoughts.

Muslim brothers as the vanguard of jihadi thought

After death of Hassan Al Bana, Brotherhood youths looked for a solution for the Egypt current situation until a book called "Maalem fe Altariq" written by Seyed Qutb was spread among Brotherhood radicalism youths which was considered increasingly and raised as strategic book.

Prisons, tortures and finally execution of Seyed Qutb and his friends to achieve these ideals were the best proved witness on it that the author of "Maalem fe Altariq" believes what is written in this book and caused to motive belief of Brotherhood youth to Seyed Qutb's book and speeches. 
After disbanding Muslim Brotherhood this book was the best source and reference among Brotherhood youths and caused to create some groups like Jamaat Al Islamiah, Al hojarat and Al takfir and AL jihad group.

\section{Bases of Seyed Qutb's Jihadi Thought}

Seyed Qutb has stated his most important Jihadi thoughts in his book "Maalem fe Altariq" and this book enjoys unique traits from which in chained and coherent materials with very beautiful and attractive literature, bringing out belief materials from theoretical to practical manner and presenting suitable supports of Quran, tradition and Prophets companions morality can be pointed to prove his beliefs and materials. These factors led Arabs to understand Seyed Qutb's Jihadi thought easily and be influenced by it. In this regard we address to the most important bases of his Jihadi thoughts.

\section{a) Twentieth century Ignorance}

In his idea, the two worlds, that is Ignorance world and Islam world are quietly incompatible and there is no coexistence and agreement between them. The truth is one and it is not divisible and everything except it, is incorrect and false and it is impossible to combine truth and false. Islam means whole obedience and submission against God and his orders; while Ignorance system is deviated from worshiping the One God and divine style for life (koppre,2001).

Seyed Qutb interprets today society's Ignorance to modern Ignorance and regards these societies very more dangerous than Ignorance age of Holy Prophet time (Seyed Qutb,2008).

He regards the most important characteristic of Ignorance as man's slavery for man and extends this trait increasingly as apparently just a few Muslims will remain on the ground. That it seems that no Muslim is remained on the ground. He says:

The most important trait determining Ignorance includes man's slavery for man in every way and also accepting lust instead deism and removing God dominance from people life and the affairs related to their material issues; people with such situation follow Ignorance whether they confess God existence or deny it; because as they take one of traits special for God's traits that is divining and sovereignty and regard it for man in different forms, in this regard if their systems and situations would have divers forms, but they'll join hands in this basic trait of Ignorance again. On the basis, Islam doesn't accept it and doesn't regard right of existence for them (Khosroshahi,2012).

If we accept that the current society can return to before Islam Ignorance and be like it, so the Muslims should see Ignorance society in eyes of Holy Prophet and his companions in their time; for example, when the Prophet saw himself in a weak situation, he selected the tactic of isolation from his society, making contact with around societies and then migration from Mecca to Medina and in powerful situation he had the tactic of battle against blasphemy and conquering Ignorance societies(Koppel, 2003).

\section{b) Governments di vision into Dar Al Islam and Non-Islam}

Seyed Qutb believe that there is just one Dar Al Islam and that is the one where Islamic government is up in it and God religion is dominant on it and God limits are brought back and the Muslims are each other friend (Seyed Qutb,2008).

Seyed Qutb believes that it is necessary to create a society where all Islam commands and rules is executed in it and just God law and religion is governor and judge in it (Seyed Qutb,2008).

Other society except it is Non-Islam or ignorant society where in Seyed Qutb idea include all mankind societies except Islamic society and on the other words, they are societies where their slavery is not special for only God (Seyed Qutb,2008).

He says in his interpretation:

The society where the only God orders and laws is not executed and just God is not bondage of (Seyed Qutb,2008), is ignorant society and Muslims relation with it, is battle or peas, based on safe-conduct or ransom (Khaje sarvi,2011).

\section{c) Thralldom and sovereignty}

There are two concepts throughout the book "Maalem fe AL Tariq":

1)Al Thralldom.2)Wisdom. (Seyed Qutb,2008). The term thralldom is originated from worship and the term Wisdom is from judging. (Seyed Qutb,2008).and from Seyed Qutb view, the government and sovereignty and so, the worship topic should be just God (Seyed Qutb,2008).

Interpreting the mean of "except Allah", in "No God except Allah", he wants to state the notion that the main issue in matters of faith is the problem of divinity and thralldom and divinity is interpreted to God sovereignty. So, no sovereignty except God sovereignty and no religion except God religion and is accepted. Finally, he concludes that anyone if the mans should not reign each other and their domination is conquest, because it is special for God. 


\section{American Islam and battle with Zionism}

One of a few people who has spoken of American Islam is Seyed Qutb. He believes in two types of Islam which would interpret one the real Islam and other American Islam. He regards Jewish hatred enjoy long record and when Holy Prophet appointing and affirm their enmity with some signs of Quran(Omidi,2011) .He who had spoken Jewish and Zionism threat repeatedly and believed that Jewish aims to dominate world and all people of the world specially Muslims should be careful, says:" the author believes that everywhere there is an invite against moral and toward adultery and depravity and lucre and war, Jewish hands is involved (Seyed Qutb,2008).

\section{d) Jihad}

One of the subjects that Seyed Qutb has emphasized repeatedly is a thought which took rational order in the period of Ibn Tamie and was employed against crusaders and moguls who had captured some part of Dar Al Islam (Omidi,2011). Then Abol Ala Modoodi (1903-1979) entered it into contemporary political literature consciously, their works affected on Seyed Qutb and he employed it about America and Israel and Zionism.

(Seyed Qutb 2002).

Seyed Qutb would regard Jihad a way to attain Islamic society and Islamic government formation and would know real Muslim the one who combat for Islam excellent9(Seyed Qutb,2012); such that he dedicates part of his book "Al jihad fi Sabil Allah" after analyzing Islamic society and ignorant society in the book "Maalem fe Al Tariq"

He knows just Jihad as the way to attain Islamic government and also the best way to confront with Jewish and Zionism and coffer and address the note I the book" (Seyed Qutb,2012).

He believed that Jihad concept should not be lowered to the limit of defensive war or limit it with believer internal combat against threats and desires and says: "If we think only with speech we can engage into Jihad, we have gone to trackless and mirage." (Seyed Qutb,2012).

Seyed Qutb refer incidentally to Islam propagation through sword and book and call both of them as each other complement on the other hand, (Seyed Qutb,2012). we see he determine Jihad against colonization incidentally (Seyed Qutb,2012) and regards necessary combat with aggressive forces of English, America and Zionism and France who have aggressed to Muslim countries like Palestine and north Africa countries and interpret it as defensive war (Seyed Qutb,2012).

Harayer dakamjian has stated Seyed Qutb ideological rules and basics as the following:

1)Non-Islamic social system is Ignorance system.

2)The believed Muslim duty is that he restores Islam life for converting ignorant society through invitation and imperialistic struggle.

3)Converting ignorant society into Islamic society is undertaken by pioneer and devoted Muslims.

4)The final goal should be confirmation of God sovereignty on the ground in order to remove all sins, pressures and suffers by this (Dakamjian,2004).

The intra-text factors of Seyed Qutb books like his speech simplicity and theoretical and intellectual Jihad orientation to practical Jihad and youth motivation toward primary Jihad, and on the other hand, external factors like war against Egypt systemic regime(Khaje sarvi, 2011).welcoming of Brotherhood radicalism youth to Seyed Qutb books and thoughts and creating the context of Jihad against atheism that it's vanguard had been created in Muslim brothers organization with the name of hidden organization, could lead the context for Arab youth the lesson that we can emprise through Jihad and forceful actions in order to reach our voice to atheism government and Jihadism should be as a permanent and universal revolution and a device to resist external capture, so after Muslim brothers in other countries did not shut down,(Khaje sarvi,Gholamreza,2011).but it caused firstly Muslim brothers transmit from Egypt to Syria and continue its policy against imperialism and colonization and communism(Eshaqh moosa,1996).

Second, excessive groups like Muslim population or the same "Al Refinement and abandon" organization led by Shekar Mustafa or Islamic population organization or "Al Jihad" group led by Abd Al Islam Faraj who were more influenced by Seyed Qutb thoughts, were created (Koppel,2008).

\section{The Factors of Al-Qaeda Formation}

In 1979, when soviet communist country entered into the Muslim country Afghanistan,(Pitral \& Ghafari,2011).first the battle was merely Afghan Jihad that it's leading was undertaken by Abd Al Rasol siaf, Golbodin Hekmatyar, Borhan Al Din Rabani and Ahmad Shah Masood, but the slow start of Jihad, when according Afghan de votees benefits with us and Arab conservative countries such as Arabia, Qatar and Kuwait in their countries freedom from communists.accelerated and became the context for creating Al-Qaeda organization((Komeil,2012).

Abd Allah Ozzam who was one of the salafists competent learned and speakers and had migrated from Arabia to 
Pakistan and would encourage Muslims to Jihad, engaged to publish Jihad magazine in 1984 and to write books about this named "defense of Islamic lands and adhesion to caravan" which the main subject of the books was calling the world Muslims to Jihad in Afghanistan and that Jihad is the duty of very Muslim person(Mostaghimi,Bahram,2010).The affairs approximate him to the reality that he had been influenced by Ibn Tamie and Seyed Qutb thoughts(Abdul al Rahim Ali,2003). Abdullah Ozzam with the help of Osama ibn Laban established "Maktab Al Khedmat" at the early of eighty decades. The second role of Osama was formed when he took some distance from Abdullah Ozzam and in the middle of the years 1986 and 1987 near soviet's casern in the eastern Afghanistan, established a base called "Al Masadeh" or the same lions forestalls for himself. Following his victories in 1987, the press called him the term pious and provided his celebrity incentives(Pitral,2011). Al-Qaeda was established at the end of decade 1980 and obviously in 1988 that its goal was overturning Arabic and communist systems and establishing Islamic caliphate(Komeil,2012). The people who had major role in Al-Qaeda establishment, include: Abu Ayoob Iraqi, Abu Al Faraj Yemeni, Imen Al zavaheri, Dr. Fazl Mesri, Abu Borhan Al kabir, Abu al hafas Mesri, Abu mosab Mesri and Ezzo Al din (Komeil,2012).

Having considered the process of Al-Qaeda creation and its goals, issues including the group influenced by Seyed Qutb thoughts can be referred to.

Pitral Bergen, political analyzer and CNN reporter believes that Al-Qaeda establishment is the result of Ben Laban separation from Abdullah Ozzam and his familiarity with Imen Al zavaheri; because Ozzam would support Jihad nature based on traditional fundamentalism, but Imen Al zavaheri and Egyptian combatants would support a more excessive concept. They believed in overturn combined with rigors of Islam world governments that in their idea were impious but Ozzam and his follower would reject the notion; because they would want no encounter is occurred (Pitral,2011).

For confirming Al-Qaeda effectiveness from Seyed Qutb thought, we have considered the debate in three basic axes (Arab de votees, Al-Qaeda leaders, Al-Qaeda goals) that with considering every axis, Al-Qaeda relation with Seyed Qutb thoughts can be comprehended well and the note should be considered that all Al-Qaeda thoughts is not the result of Seyed Qutb thoughts and Ibn Tamie thoughts effectiveness in Al-Qaeda can be seen clearly that its analyze is out of the article limit. So, Al-Qaeda thought should be regarded as a combination of Seyed Qutb Jihadi thought and Wahhabism salafi thoughts.

\section{1) Arab devotees}

People who entered Afghanistan from Arab countries for the purpose of supporting Afghanistan Muslim country and combat against communist were famous to Arab devotees that after Jihad ending in Afghanistan and concurrently with devotee's reference to their countries, Osama Ibn Laban organized them under a group called Al-Qaeda for the purpose of using them in different countries and creating Islamic army for confronting with corrupt rulers and creating Islamic government. Al-Qaeda can be divided into four general group:

1) Universal formations of Muslim brothers

2) Brigades of Taw heed in Arabia

3) The group of "Jahiman Al Atibi" in Arabia

4) Sunni Baathists in Iraq

Whether all Arab devotees are influenced by a thought (polar) or several thought (polar and Wahhabism) or whether they had been influenced by people or group, need separate definite, is that many Arabic devotees who had moved for Jihad toward Afghanistan had been originated from Egypt Jihadi group and influenced by Seyed Qutb thoughts;(Bergan, Pitral,2011) so that in an important document that imply the first minutes of Al-Qaeda establishment, Al jihad group is being referred to and is given: "but our Egyptian brothers; they are were beside us in the darkest conditions and it is not something than can be forgotten",( Bergan, Pitral,2011). Historical witnesses indicate that in decade 80, after Anvar Sadat terror in the country Egypt, there was no place for devotee's activity in Egypt. So we see major people like Imen Al zavaheri and before he, Seyed Imam famous to Abd al qader Ibn Abd al Aziz and the engineer Mohammad, the brother of Imen al zavaheri, were among people who migrated to Afghanistan (Komeil,2012).

Muslim brothers that had converted to a universal organization and had effected many groups throughout the world, equipped the devotees of Mustafa Boiali movement famous to Islamic movement in al Jazeera and failed in initial attempt in 1982 for overturning governmental system and having been killed Boiali in 1987, the movement work was ended and most of its members were captured or migrated to Afghanistan. Most of the movement members were associated with local branch of Muslim brothers led by sheikh Mahfouz Nahnah and he also had active cooperation in them transmit to Afghanistan (Komeil,2012).

Syrian devotees in the first half of decade 80 , failed as a result of Hemah events and eradicating brother's intifada and fight pioneers and their attempts were failed for returning to Syria. So they went Afghanistan in 1988 that Abu Mosab 
soori is one of them. Libyan devotees were not exceptional from the rule and most of them had activity against system in the years 86-89 and had involved with security forces repeatedly and Libyan official had responded them with putting them in prison and found that the Jihad time is not reached. So they migrated to Afghanistan. So Arab de votees were often among groups who were influenced by Muslim brother's organization and would migrate Afghanistan after their plans failure. After Arab youth migration to Afghanistan, other active groups like Egypt Muslim brothers and Al Jihad and some Wahhabis salafi learned tried to dissipate their thoughts among Arab Afghans in order to could hunt someone who are not organized until now and were void of any intellectual found. The top of the groups, there were Egypt Al Jamaat and Al Jihad groups who had got their policy from Seyed Qutb and Abdul Al Islam Faraj books. The two groups created a group called Jamaat Al Jihad and published their emir book, Dr. Seyed Imam Sharif called Al Omde fi Adad $\mathrm{Al}$ edeh that would distribute and teach as a basic reference among camps (Komeil,2012).

\section{2) Al-Qaeda leaders}

The group leaders were often influenced by Seyed Qutb thoughts. Osama Ibn Laban who would regarded as the Al-Qaeda first person and its major leader, first was influenced by his father Mohammad and would like him very much and would imitate him. He missed his father at ten years old. His father was very anti-Israel and Jewish; Because he believed that Palestine is dependent on Arabs. (Bergan, Pitral,2011). Jamal kalife, Ben Laban classmate friend, says that Ben Laban would read Seyed Qutb works from student period. He also says: we would read Seyed Qutb books, Mohammad Qutb, the brother of Seyed Qutb, who was the professor of Malek Abdul Aziz university at the late of decade 1970, would give usually lectures to me and Ben Laban (Bergan,2011).

Changing Ben Laban approach after separation from Abd Allah Ozzam and familiarity with Imen zavaheri, can be a coherent document for Ben Laban being influenced by Seyed Qutb; such that, according to documents which were published at the initial minutes of Al-Qaeda formation Ben Laban regards Al-Qaeda formation interested by his Egyptian brothers (that is, Al Jihad and Imen zavaheri group) in addition to opposed with Abdullah Ozzam. (Bergan,2011).

Having considered his speeches and words, the signs of Seyed Qutb thoughts effect can be seen clearly. He refers to Seyed Qutb world deliberately and says: Mohammad Islam should be dominated throughout the earth, not it remains in worshipping rituals (Ben Ladan,2009). He knows the victory for Muslims and Islam with referring to Palestine freedom and dominance on Jewish (Ladan,2009). He also regards the book "Concepts and indulgence" written by Mohammad Qutb as one of the best books of present century (Ben Ladan,2009).

Al zavaheri is regarded as second Al-Qaeda leader from score aspect. He would know his liberality indebted by Seyed Qutb in his description in 2001 under the little of $<<$ knights under the Prophet flag $>$. (Bergan, Pitral,2011).He greets in some of his words for whom have vitalized Syed Qutb way and says: They requested before Seyed Qutb hanging that he request forgiveness, but he responded: the fingers that have witnessed God unity in every prayer, do not request forgiveness from cruel, Seyed Qutb said courtier learned who had duty on behalf of government to give dictation him before hanging: you follow non-God, but we die in the way of Allah. The action of Seyed Qutb caused creation of basic and manhaj law in order to fundamentalists consider their law principles again.

Imen al zavaheri in other part of his words regards Seyed Qutb as Islam martyrdom and reading his book "fe zelal Al Quran” as man cure from pain and darkness. He narrates from Seyed Qutb that Seyed Qutb would emphasize on unity position in Islam and would regard unity as a criterion between Islam and theism and believed that ruler and king order and laws should be on unity axis. The words effects in recognizing Islamic movement was clear for Islam enemies and whom Islam is regarded as a threat for them and Islam recognition because we found the threat of some internal enemies is not less than external enemies; because the groups are hired enemies of external enemies in order to hide themselves behind them and strike Islam(Zavaheri,2009).

Imen Al zavaheri emphasized that although Abdullah Naser could suppress Seyed Qutb and his flowers, but he never could prevent the effect of Seyed Qutb thoughts among Muslim youth(Mohammad,2005).

Imen Al zavaheri who was the leader of Egypt "Jamaat Al Jihad" group in 1993, colligated with Ben Laban in 1998 and created a unit deploy called<< Islamic universal deploy > (Mohammad,2005).

Montaser Al ziat and vakil al zavaheri believe that Imen Al zavaheri had a key role in Al-Qaeda organization; such that Ben Laban intellectual change was started after his familiarity with zavaheri. He visited zavaheri for the first time in Peshawar in 1986 and was converted from a pure salafi to a radical salafi possessing Jihadi thoughts gradually (Komeil,2012).

\section{3) Al-Qaeda goals and beliefs}

From Al-Qaeda view, religion is a simple and legal system that God has imposed in order to the mans can acquire a suitable reward in paradise with executing God orders in addition to their rescue from hereafter torment. They believe 
that if the man's act God laws with Wahhabis and salafi interpretation, can be happy in the world and hereafter.

They believe that acquiring God satisfaction who is the world king is not attained easily and most time, reaching the stage would not be possible without sacrifices and blood volcanos. So Jihad element in Al-Qaeda thought has very high importance and is regarded as their main and most efficient device and ideology; such that Al-Qaeda leaders know it more important than other religious worships like prayer, fast and hajj. They believe that the Muslims who have not engaged to Jihad in the way of Allah and because of the reason(Zavaheri,2006) Ben Laban announced Jihad with the name of Islam universal deploy in February, (Laban,2009)1998 and issued the order of holy war against apostates and ordered his followers to kill America people and its allies(Mostaghimi,2010).

According to Al-Qaeda ideology, belief or non-belief determines the border among humans that everyone who follows their intellectual school is called friend and Muslim and who oppose it, enemy and impious. They tried to make their ideology effective for combat. (Islamia,2007) Imen Al zavaheri writes in his book: Islamic rulers have spruned divine sharia and orders and have become friend with Jewish and Christians ... despite of their being Muslim claim, they have fallen away from Tula and ax belief more than other groups(Zavaheri,2009).

The group threat for Islam nation is extended to the extent that it is regarded as the greatest factor of Islamic nation deviation from their belief.

He divides Sunni into several groups:

1) Public: they are a present and silent majority

2) learned and elites

3) Brothers: he insults brothers severely and call them acute people who want to build government for themselves with cheating youth

4) Devotees: it knows de votees as Sunni sincere and the abstract of best Sunni regions 5. Immigrants: they are also real Muslim, although their number is little.

Al-Qaeda excommunicate most Muslims using the words unity and idolatrous. Imen al zavaheri says:

You think the worship is just prayer and fast, but I tell you the worship is not such that you have limit comprehension of it, but it is more extensive and comprehensive. The word unity that God created the creatures for it and send Prophet and revealed book for it.

Includes the word $<<$ No God except Allah $\gg$ that is divided into two sections:

1) section that there is no idol except God that divinity is negated from non-God

2) Positive just for God and that is in all small and big affairs, non-God is not followed... Idolatrous in word means everything that is worshiped. The idol, sometimes grave and sometimes law and ...

As Ibn Tamie says: everyone who leave the knowledge that is comprehended from the God book and his Prophet and follow the order of the ruler who is opposed with God order and his Prophet, is impious in the world and hereafter and deserve sanction.

Zavaheri, because Seyed Qutb knows unity of two categories $<<$ No God $\gg$ and $<<$ except Allah $\gg$ and then define idolatrous in idiom mean to everything that is worshipped to non-God and refer to its different forms and says: in the first pagan Dom, the people would worship idol and kill for their graves and figurative Gods, but in the present era, the people worship the same Gods and just their forms have varied with each other, in their view, the factors like:

1) help impious

2) Cursing to Prophet companions specially Abu-Bakr, Omar

3) Acquiescence to impious government and fear and nerveless against them cause to blasphemy(Zavaheri,2009).

Combating with the west and America, would regarded as one of Al-Qaeda concerns and Ben Laban always would criticized who have been seeking a political approach for solving issue with Europe and west and believed that death is better than living in Europe or Imen $\mathrm{Al}$ zavaheri was very concerned that devotees children are influenced by European life, Osama Ibn Laban says about America: although America is a big government and enjoy powerful military and universal economy, but it has fragile points where we can void it from universal power and extinct its aggression with setting a goal that weal points. Or Imen Al zavaheri in a letter to Sheikh Hassan Turkey writes: there is no news in Americans and our goal from being together under Al-Qaeda organization is Jihad against enemy(Omidi,2006).

Ben Laban in a letter dating 1994/07/17 advices Ben Baz, Arabia Salafi taught who indult peace with America and call America idolatrous country and regards its rulers as impious and warn such indult consequences (Khaje sarvi,1994). 
From the mentioned words and many other witnesses, it becomes obvious well that Al-Qaeda leaders following Seyed Qutb call many governments illegal using the terms like unity, idolatrous and pagan Dom. On the other hand, knows America and Zionism as Islam enemy in the first stage and try to introduce Jihad the only way of confronting them with different interpretations.

In Al-Qaeda view, active jurisprudence is the same as Jihad and pragmatic jurisprudence. So, zavaheri narrated from Seyed Qutb says:

Evolution of Islamic jurisprudence is made only in the area of movement and activity and should not be expected from a Juris consult who has set aside when society movement and activity. In the period, ones who are involved with book and notebook and try to deduce judicial orders from that resources and aim to revive far from practical activities, have not realized the religion nature and character really and are unable in recognizing religion jurisprudence. They have combined the ideas such that they give legacy to rampancy, attachment and corrupt and loot of impious and out of sharia ruler. (Omidi,2011).

It should be noticed that all Al-Qaeda leaders had not a unite thought; for example, zavaheri had aggressive thought and would know priority combat against Shiites, contrary to Al zavaheri who would give priority to combat with the west and America or zarqhavi would call all Arabian governments impious, but Ben Ladan would except some countries specially Arabia in the primary stages, but while Al-Qaeda organization enjoyed a unit and long term plan and would always set out four its activities:

1) America is the biggest obstacle for creation of Islamic government; so, it should be destroyed.

2) Downing America follower and UN hollowing regimes in Middle East.

3)Destroying Jewish government in Israel and its replacement with a Muslim government in Palestine.

4 (Al-Qaeda wants to maintain Islamic discipline in the world that the work is done by fundamentalisms and be under leading a caliph. Finally, their plans were toward creating an Islamic government and in Seyed Qutb word, Dar Al Islam. So they would try to withstand ignorant society or Non-Islam and combat it.

(Atavan,2007).

\section{Conclusion}

Regarding to the space and conditions that is created for Muslim brothers, Seyed Qutb death caused his books and thoughts is put into consideration of many brothers' radical youth; such that his books were put the reference of his plans and his thoughts caused creating different Jihadi and Takfiri groups within brothers.

Soviet invasion to Afghanistan become an excuse for Arab devotes to gather and Ben Laban put them under a unit organization called Al-Qaeda.

Trainings that Arab de votees would receive and learn from Al Jamaat and Al Jihad group, would lead Al-Qaeda toward Seyed Qutb thoughts and on the other hand, Al-Qaeda leaders like Ben Laban and Imen zavaheri had been influenced by Seyed Qutb thoughts. So when we see Al-Qaeda beliefs a goals, it can be concluded clearly that the organization with understanding have had from Seyed Qutb thoughts, has been able to plan the goals and principles for himself, although it may have much disagreement from judicial or belief aspect with Seyed Qutb.

\section{References}

Seyed, Q. (2002). "darasat AL Eslamia,” Beirut: Dar Al shoroq, 18.

Seyed, Q. (2008). “the traits of Islamic ideology”, translator: Ali Hojat kermani, Tehran, Binna, 247\&247.

Seyed, Q. (2008). “the traits of Islamic ideology”, translator: Seyed Mohammad Qameneyi, 185.

Seyed, Q. (2008). “the way signs”, translator: Khosroshahi, Qom: Markaze Al boohoos Al alamye, 194 \& 264.

Seyed, Q. (2009). "Moalem Fe Al Tariq”, Qahere: Al Etihad Al Eslamia AL Alami, Bita, 132.

Seyed, Q. (2012). "what we say”, hadi Khosroshahi, Tehran: Islamic culture, 169.

Seyed, Q. (1413). “Marakatana ma al yahood”, Beirut: Dar Al sharqh, 128.

Abdul, al R. A. (2003). "Half Al Arhab Tanzim Al-Qaeda”, Qahere: Markaze Al mahroosat, 66.

Atavan, A. B. (2007). “Al-Qaeda, Tanzim Al Seri”, Beirut: Dar Al saqi, 48.

Azdi, Abbie jondal, Osama Ibn Laban Mojadad Al zaman, adopted from Tohid and Menbar, 69.

Ben Laban, O. (2009). "Arshif Jameol kalemat VA khatabat sheikh Osama”, adopted from Tohid and menbar, 24.

Bergan, P. (2011) "Osama Ibn Laban, translator; Abbas qholi Ghafari Fard, Tehran: Ettelaat, 36.

Dakamjian, H. (2004). "contemporary Islamic movements in Arab world”, translator: Hamid Ahmadi, Tehran: Keyhan, 
fourth edition, 83 .

Gil, K. (2003). 'the Prophet and feron”, translator: Hamid Ahmadi, Tehran: Keyhan, third edition, 72.

Hussein, E. M. (1996). "Muslim brothers the biggest Islamic movement", translator: Khosroshahi, Tehran: information institution, 25.

Hussein, E. M. (2002) “Al vela Al Bara, Aqhide manqhole VA vaqhe mafghood”, Bija, bina, 153,

Ibrahim, M. etc. (2005). “Egypt Muslim brothers”, Tehran: Andishe sazan, 73.

Islamia, H. (2007). “Al-Qaeda from image to extant”, Tehran: Andishe sazan Noor, 59.

Khaje sarvi, G. (2011). "Islamic awareness in the extent of universal policy”, Tehran: Imam Sadeqh university, 7.

Komeil T. (2012). Al-Qaeda and its sisters, Tehran: Andishe sazan Noor, 19.

Moradi, M. (2003). “impressing Seyed Qutb conversation”, Tehran: political science publication, 21.

Mostaghimi, B. (2010). 'The principles and concepts of Al-Qaeda political Islam”, Tehran: policy periodic letter political science and law college, period 40, N3, 135.

Omidi, Y. A. (2011). “All Qaeda”, llama, Johare Hayat, 62.

Seyed, Q. (2008) “the traits of Islamic ideology”, translator: Ali Hojat kermani, Tehran, Binna, 247.

Zavaheri, A. M. (2006). "kalemat Al maziha”, Shabeke Al Barqh Al Islamiat, 146.

\section{Copyrights}

Copyright for this article is retained by the author(s), with first publication rights granted to the journal.

This is an open-access article distributed under the terms and conditions of the Creative Commons Attribution license which permits unrestricted use, distribution, and reproduction in any medium, provided the original work is properly cited. 